\title{
Pyrolysis of Waste Plastic and use of Plastic Oil as an Alternate Fuel in Diesel Engine
}

\author{
${ }^{[1]}$ Nagaraj Shivakumar Biradar \\ (M. Tech.) \\ PDA College of Engineering, Kalaburagi-Karnataka
}

\author{
${ }^{[2]}$ Dr. Omprakash Hebbal (Ph.D.) \\ Professor, Department of Mechanical Engineering \\ Pda College of Engineering, Kalaburagi-Karnataka
}

\begin{abstract}
Plastic is versatile, light weight, moisture, resistance strong, and relatively inexpensive. This inherent quality of the plastic made it an integral part of daily life and as a result of which polymer products becoming massive scale worldwide. On an average $\mathbf{1 1 0}$ million tonnes of plastic is produced per year globally. Among this India produces 14088 KTA thermoplastic in a year. About $70 \%$ of plastic products after use converted into waste in a short span. Approximately 9.4 million tonnes per TPA generated in a country which 26000 TPD. A proper plastic management system shall be developed to mitigate problems arising. $80 \%$ of plastic is recycled and remaining indispensable. These waste plastic is pyrolated to convert into useful liquid fuel. In the present study an attempt is made to convert waste polyethylene milk pouches into oil in a batch reactor. The oil is characterized and found that suitable to use as a fuel in diesel engine, due to favourable properties of plastic oil it is mixed with diesel at $10 \%, 20 \%$ and $30 \%$ by volume basics. This blend is used to run a single cylinder diesel engine and to evaluate combustion, emission and performances characteristics. The yield of plastic oil is higher for 460 o $\mathrm{C}$ i.e. $784 \mathrm{grams} / \mathrm{kg}$. It is found that brake thermal efficiency of plastic oil blend with diesel is having higher than that of neat

diesel. Further as the percentage of plastic oil in the diesel increases the brake thermal efficiency also increases. However emissions of the NO $X$ for the blends are higher than that of neat diesel and this attributes to oxygen molecule availability in plastic oil.
\end{abstract}

Keywords: Pyrolysis, Waste plastics, Plastic oil

\section{INTRODUCTION}

Plastic is versatile, light weight, flexible, moisture resistance, strong and relatively inexpensive. Those are attractive quality lead us around the world, to such voracious appetite and over consuming of plastic goods. Plastic products have become an integral part of daily life as a result of which the polymer products massive scale worldwide [1].Fig 1.1 shows cumulative global plastic production. In last 65 years the global plastic production increases to 7 million tonnes. On an average production of plastic crosses 110 million tonnes per year globally. Its broad range of application in packing films, raping materials, shopping and garbage bag ,clothing ,toes, house hold and building materials etc.

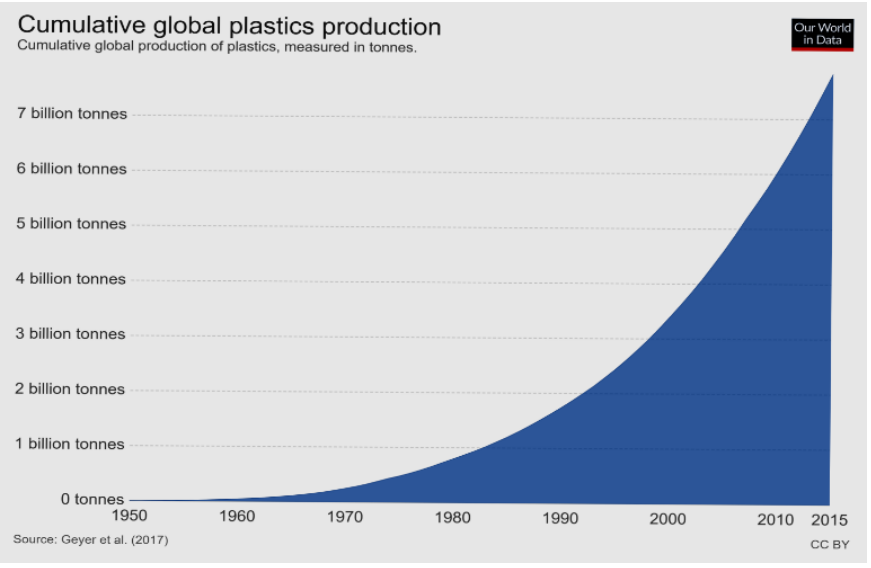

Fig 1.1 Cumulative global plastics production

India being second highest GDP and highest GDP growth rate among BRICS countries has $+7.1 \%$ growth in 2016 [2] .This GDP growth has strong relation to petrochemical growth that is polymer consumption growth. Agriculture, health care, solar energy, packing sector, defence, automobile production and "Make in India" where initiative to attract investment to sustain GDP. Fig 1.2(a) shows total export and Fig 1.2 (b) shows total import during 2016-17. 13\% of total import are resin plastic materials. About $14088 \mathrm{KTA}$ is major production of thermoplastic production in India. Fig 1.3 shows major plant location of different polymers such as PS/PES, LDPE, LLDPE, HDPE, PP, PET, PVC etc. Fig 1.4 shows the total different polymer consumption in 2016-17 and consumption amounts to $15500 \mathrm{KT}$. Average per capita consumption of plastic in India is $11 \mathrm{kgs}$ against $109 \mathrm{~kg}$ of US, $65 \mathrm{~kg}$ of Europe, and $38 \mathrm{~kg}$ of China and $32 \mathrm{~kg}$ of Brazil. Higher per capital consumption of plastic is an indicative of developed countries [3]. 


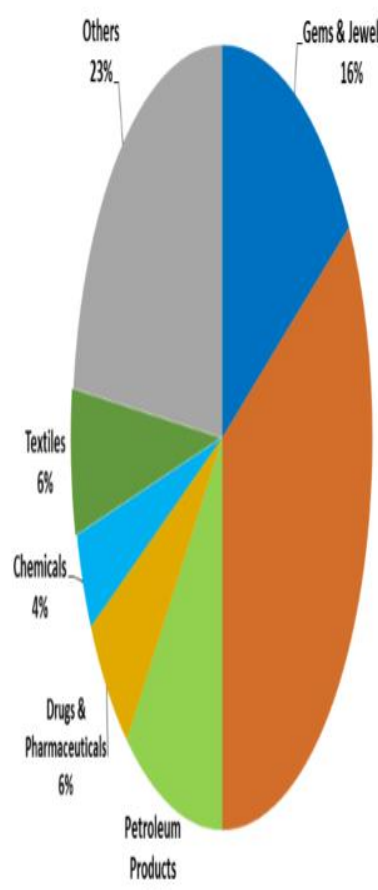

$11 \%$

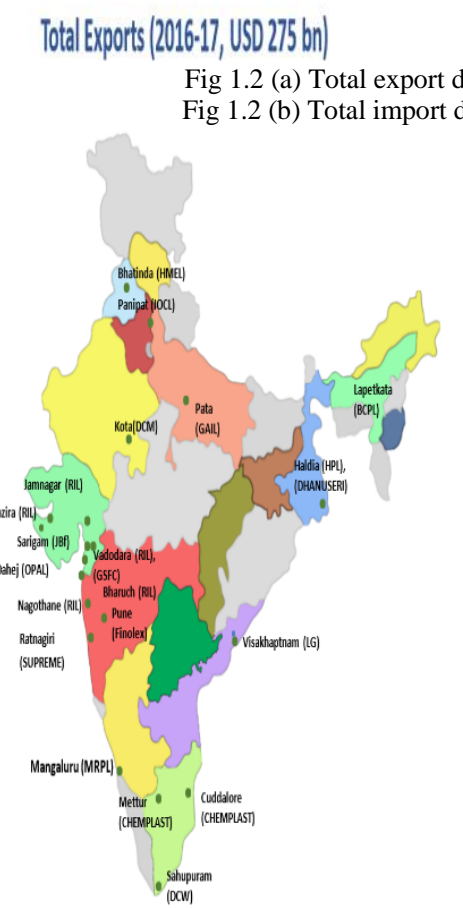

Fig 1.3 Major plant location of different polymer

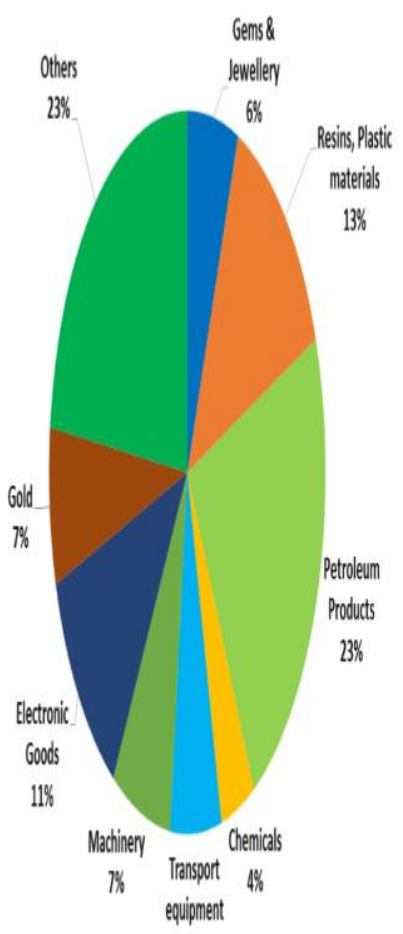

$6 \%$

\section{Total | Imports (2016-17, USD 380 bn)}

Fig 1.2 (a) Total export during 2016-17

Fig 1.2 (b) Total import during 2016-17

\begin{tabular}{|c|c|c|}
\hline Polymer & $2016-17$ & $2019-2$ \\
\hline PS/EPS & 599 & 599 \\
\hline LDPE & 205 & 605 \\
\hline LLPE & 1700 & 2300 \\
\hline HDPE & 2855 & 2855 \\
\hline PP & 4970 & 5670 \\
\hline PET & 2072 & 2072 \\
\hline PVC & 1435 & 1435 \\
\hline Others & 252 & 252 \\
\hline Total & 14088 & 15788 \\
\hline
\end{tabular}

|Figs in |
Total Polymer Consumption : 2016-17 (Thermoplastic + Thermoset)

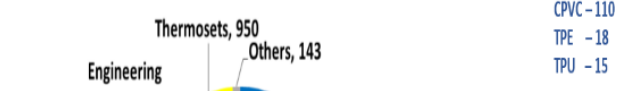

(Figs in KTA |

\section{Consumption 15500KT (2016/17) 20000KT (2019/20):- 9\% CARG PLASTINDIR: SOURC: PPASTINDA FOUNDATIO}

Fig 1.4 Total polymer consumption in 2016-17

A complication of mismanaged plastic waste in environment is a global growing concern. It is estimated that about 80 million metric tonnes of plastic waste were produced globally in 2015 [4].

In India it is estimated that approximate $70 \%$ of plastic making product converted into plastic waste in a short span. Approximately 9.4 million TPA plastic wastes generated in country, which amount to 26000 TPD. Of this $60 \%$ is recycled, most of the informed sector. While recycling rate in India is considerably higher than the global average of $20 \%$, there is still over 9400 tonnes plastic waste which either landfills or ends up with polluting streams or ground water resource. While some kinds of plastic do not decompose at all, other could take up 450 years to break down [1]. The recycling of a virgin plastic material can be done 2-3 times only because after very recycling, the plastic material deteriorate due to thermal pressure and its life span is reduced.

Plastic waste management rules in 2016 where enforced from Govt of India on 18 march 2016, in which fixes responsibility on local body, Gram panchayat, manufacture importer to reduce, reuse, recycle and recover the plastic waste. Under recycling depolymerisation plastic to fuel, plasma pyrolysis technology is major. A new generation of conversion of technology specially designed to manage non-recyclable has been developed and commercial scale facilities that use pyrolysis technology to convert to plastic into oil and fuel are established in Europe and Asia. Pyrolysis is thermal decomposition of material at elevated temperature in an inert atmosphere. Pyrolysis has the benefit of transferring non-recyclable plastic waste into valuable compounded and creating a reliable source of alternative energy from an abundant, no/low cost feedstock.

In this project an attempt is made to identify low cost local available feedstock i.e. LDPE milk pouches. The estimated the quantity of pouches per day in our district milk pouches 
is $4,60,000$. The total weight of milk waste pouches is turned to be around $920 \mathrm{~kg}$ per day. The batch reactor available in the laboratory is used to produce pyrolytic oil from milk pouches. Its characterization is carried out physio-chemical, thermal properties of pyrolytic oil is compared with that of conversion fuel diesel. Further pyrolytic waste plastic oil is used as fuel to run a diesel engine. The combustion, emission and performances characteristics were evaluated.

\subsection{SUMMARY ON LITERATURE REVIEW}

- 80 million metric tonnes of plastic waste in the world per year, whereas the China alone produces the $25 \%$ of world plastic wastes.

- India produces approximately 9.4 million tonnes per annually of plastic waste, out of this $70 \%$ of plastic is discarded as waste.

- Nearly $60 \%$ of plastic waste is recycled and $20 \%$ are either landfills or ends up with polluting streams.

- Different types of plastics such as PE, LDPE, HDPE, PS etc and their properties are studied.

- Different types of pyrolytic reactors are designed, tested and are in use. Batch and semi batch reactor is simplest reactor and there working principle, construction and variables affecting their operations were presented.

- The process parameters, physical and chemical properties of different plastics waste oil are studied.

- The favourable properties enable to use as fuel in boiler furnace, internal combustion engine etc.

- The recycling of a virgin plastic material can be done 2-3 times only because after very recycling, the plastic material deteriorate due to thermal pressure and its life span is reduced.

\subsection{GAP ANALYSIS}

- Plastic is a bone because they are strong, corrosive resistant and inexpensive. Per capita consumption of developed country is higher than that of developing country such as India. But it is a bane because the plastics used in the daily life becomes a scrap within no time which creates environmental pollution related problems.

- All plastic waste cannot be recycled. Some of them are used for land filling, after some years even the land filled plastic will be speeded over the larger area and pollutes.

- In Kalburgi city milk will be supplied by Karnataka Milk Federation (KMF), Dudhpandhari from Maharashtra and from other local petty producers. KMF alone produces and sales 4, 60,000 milk packets per day within no time plastic pouches convert into wastes. The estimated total weight of these LDPE plastics is equal to $920 \mathrm{kgs}$ per day. The plastic wastes will be collected by the large number of waste pickers.

\subsection{OBJECTIVE OF PROJECT}

In this previous para it is observed that nearly one tonne of plastic waste is produced from a milk producers unit. Such milk packs can be collected and converted into useful commodity. The batch pyrolytic reactor available in the laboratory of mechanical engineering department may be used to convert these plastic wastes into useful pyrolytic oil. Further this pyrolytic oil is used in internal combustion engine, boiler, and furnace as fuel.

\subsection{STATEMENT OF THE PROJECT}

The statement of the project is as follows

- Waste plastic pouches were collected from Karnataka Milk Federation [KMF]. This plastic pouches were cut short in small pieces.

- $\quad$ FTIR and TGA analysis of plastic collected from KMF were carried out.

- Based on the TGA analysis the waste plastic yield at $430^{\circ} \mathrm{C}, \quad 460^{\circ} \mathrm{C}$ and $490^{\circ} \mathrm{C}$ were experimentally determined.

- Thermo physical properties of waste plastic oil determined and compared with that of diesel.

- $\quad$ FTIR of the waste plastic oil is carried out at Ceramics and cement technology department of our college.

Waste plastic oil at $10 \%, 20 \%$ and $30 \%$ of volume is blended with diesel. Further these blends are used to run a single cylinder diesel engine to evaluate combustion, emission and performance characteristics.

\subsection{SCOPE OF THE PROJECT}

Output of the project gives a practical solution to mitigate problems arising by waste plastic at local.

\subsection{Introduction}

\section{EXPERIMENTATION}

In continuation with pervious chapter experimentation on pyrolysis of waste plastic pouches is explained in this chapter. The batch reactor available in the laboratory is reconditioned to work satisfactorily. An experiment is conducted on this batch reactor and yield of waste plastic oil is measured. Physio-thermal properties of the waste plastic oil are determined. Further this waste plastic oil with $10 \%, 20 \%$ and $30 \%$ is blended with diesel on volume basis and blends are used to run a DI diesel engine to evaluate the combustion, emission and performance characteristics.

\subsection{Waste plastic pouches}

Waste plastic pouches were collected from Karnataka Milk Federation unit of Kalburgi. It is observed that on an average 4, 60,000 pouches are needed for packing of milk, curd, butter milk etc per day. The estimated milk waste plastic pouches are $920 \mathrm{kgs}$ per month. The local available waste plastic pouches are considered for experimentation to find solution for disposal at local level. For every trail $1 \mathrm{~kg}$ of waste plastic pouches were taken and reduced to micro pieces.

\subsection{Batch type reactor}

A batch type reactor available in the laboratory is considered for pyrolysis of waste plastic. Fig 3.1 shows schematic flow diagram of waste plastic and Fig 3.2 shows the photograph of pyrolytic reactor [31]. The pyrolysis process is carried in a reactor where PID controller is used to control the temperature bricks. The reactor is made of 
mild steel and to minimize heat losses it is insulated with refractory. The length of reactor is $56 \mathrm{~cm}$ with the internal and external diameter of 21 and $56 \mathrm{~cm}$ respectively. The length of the condenser is $140 \mathrm{~cm}$ having inner and outer diameter of pipe is 1.905 and $3.81 \mathrm{~cm}$. The inner pipe is made up of galvanized iron (GI) and outer with copper material.

The vapour residence time in the reactor is maintained around 10 seconds. Water is used to condense the vapour coming out of reactor. The nichrome coil having capacity of $3 \mathrm{~kW}$ is used to heat the reactor and $\mathrm{J}$ type thermocouple having range of -99 to $870^{\circ} \mathrm{C}$ is used to measure the temperature of biomass [31].

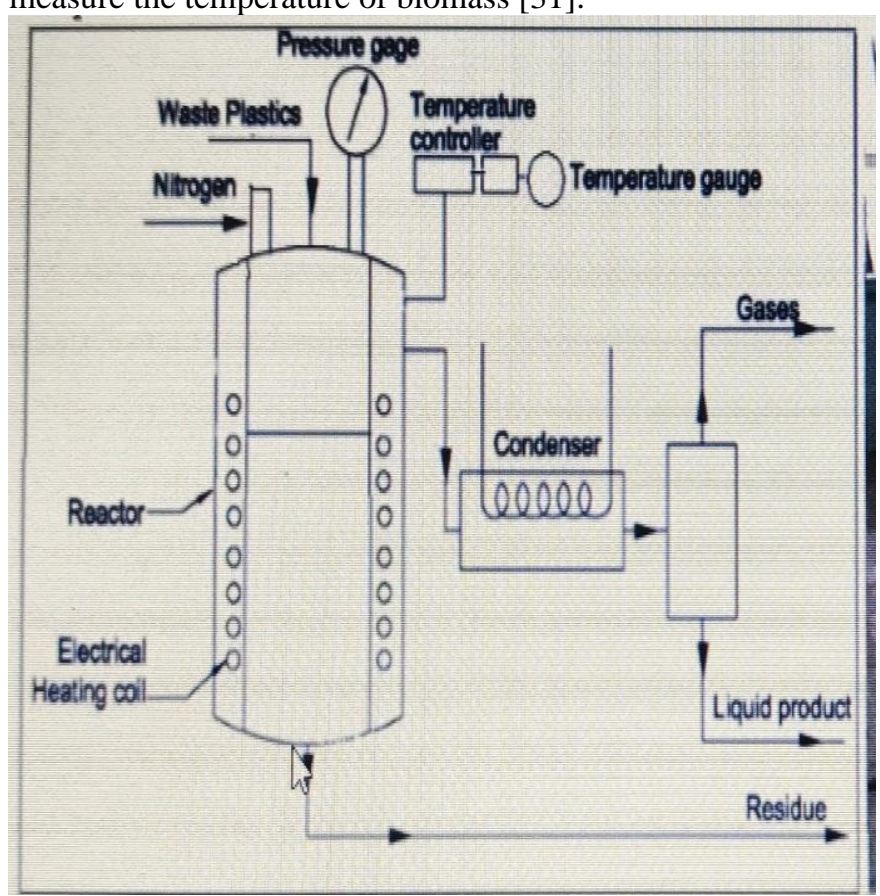

Fig 3.1 Schematic diagram of waste plastic pyrolytic reactor

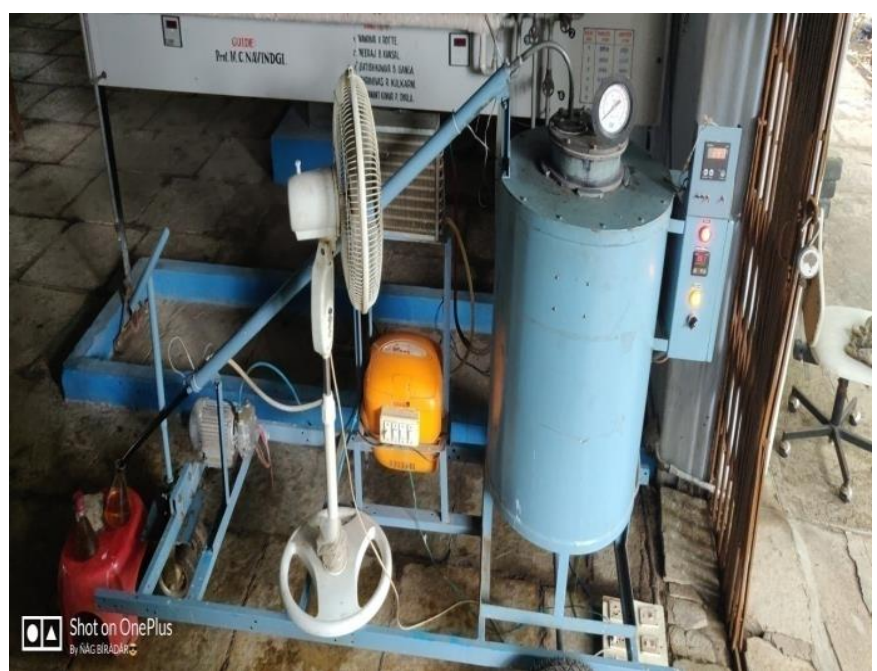

Fig 3.2 Photograph of pyrolytic reactor

\subsection{Pyrolysis}

Fourier transforms infrared spectroscopy (FTIR) analysis and thermo gravimetric analysis (TGA) is carried out at Kelvin labs Hyderabad. Fig 3.3 shows the FTIR analysis of plastic waste considered in experimentation. It is observed that the waste milk pouches considered for the experimentation is polyethylene i.e. LDPE (Low density polyethylene). Fig 3.4 shows the TGA analysis of waste milk pouch plastic. From analysis it is observed that LDPE content is $98.9 \%$, volatile material is $0.2 \%$ and ash content is $0.9 \%$. Converting the plastic into oil initiate at $280^{\circ} \mathrm{C}$ and likely to end by $520^{\circ} \mathrm{C}$. Based on the TGA analysis for each test $1 \mathrm{~kg}$ of waste plastic is considered for pyrolysis. The yield of $1 \mathrm{~kg}$ of waste plastic is determined at three different temperature i.e. $430^{\circ} \mathrm{C}, 460^{\circ} \mathrm{C}$ and $490^{\circ} \mathrm{C}$ respectively. The oil collected and ash left in the reactor is measured and difference of these two from $1 \mathrm{~kg}$ gives mass of gas released.

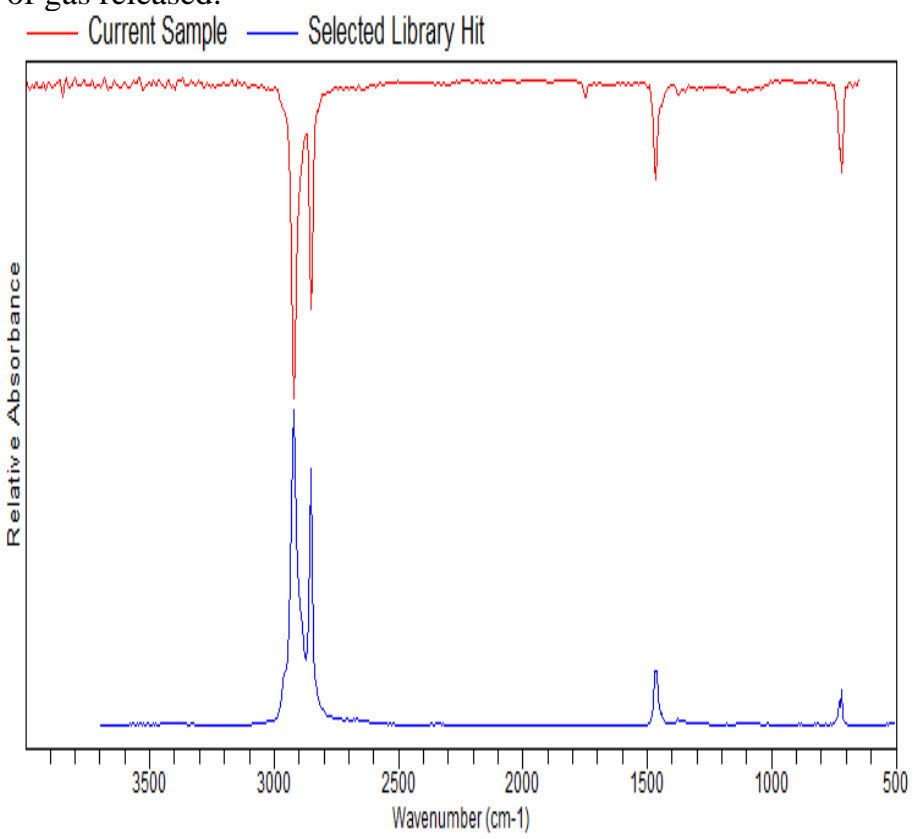

Fig 3.3 FTIR analysis of waste plastic

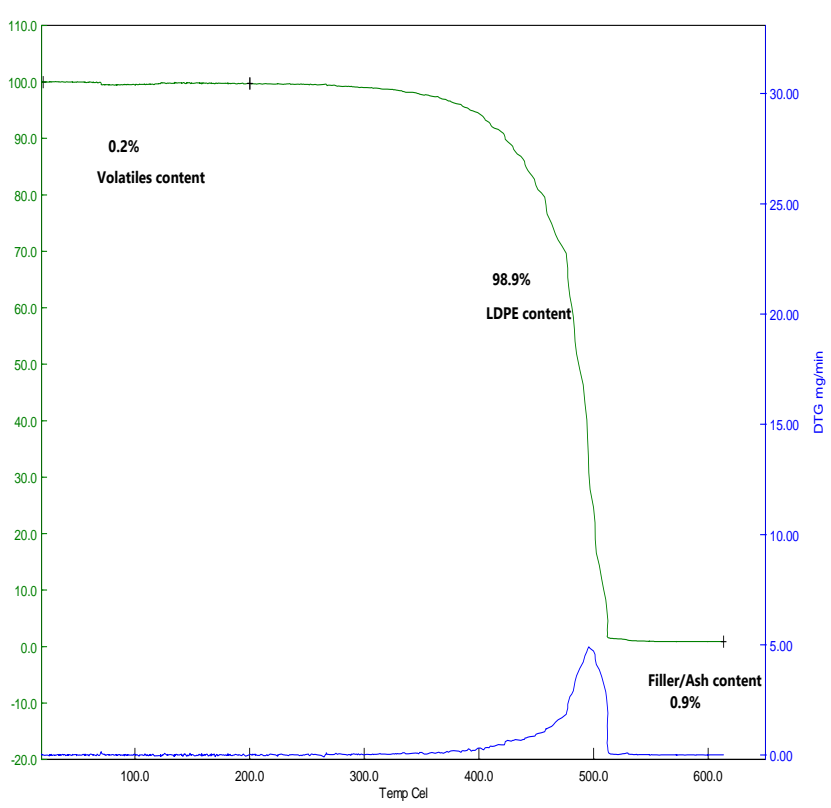

Fig 3.4 TGA analysis of waste plastic

\subsection{Diesel engine}

The plastic oil collected during the pyrolysis is characterized. This plastic oil is blended with diesel at 
$10 \%, 20 \%$ and $30 \%$ on volume bases with diesel and blend is prepared. These blend where used as fuel for running a DI diesel engine. The combustion, emission and performances characteristics of diesel engine with these blends are evaluated and result are compared with that of neat diesel. The schematic diagram and photograph of the DI diesel engine shown in Fig 3.4 and Fig 3.5. The specification of the engine used for testing is shown in the Table 3.1.

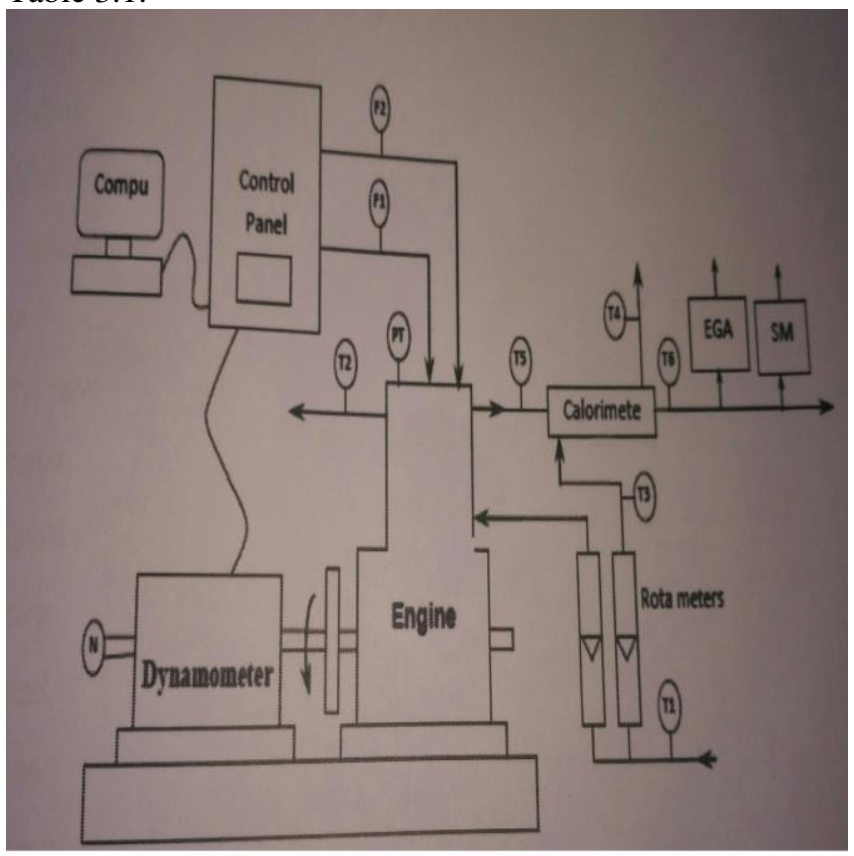

Fig 3.5 Line diagram of the experimental setup

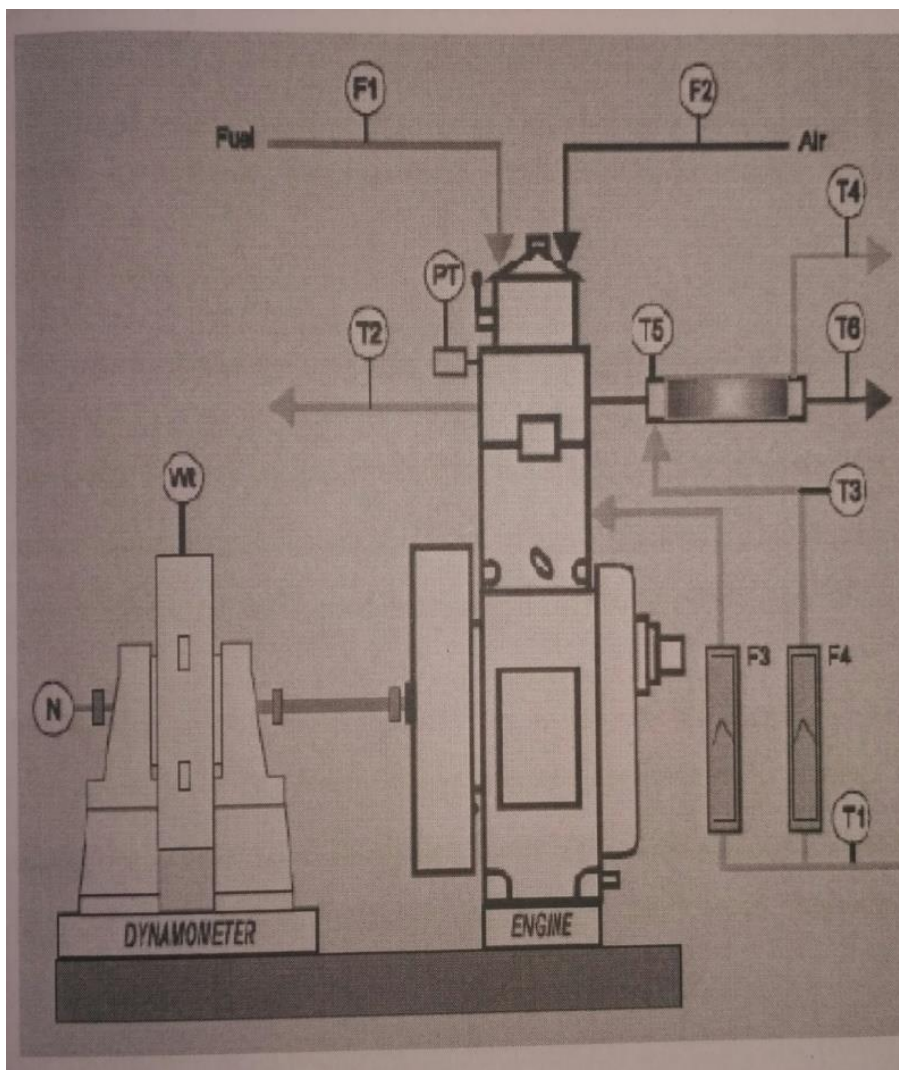

Fig 3.6 Experimental setup with instrumentation

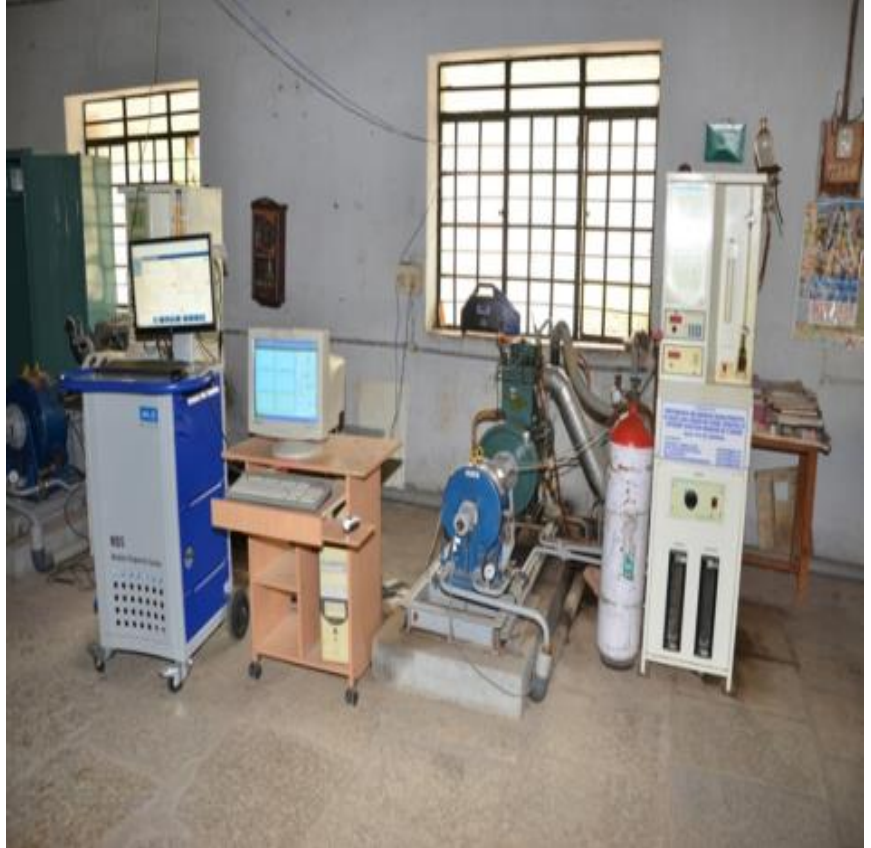

Fig 3.7 Photograph of the DI diesel engine

Table 3.1 Specification of the diesel engine

\begin{tabular}{ll}
\hline Manufacture & Kirloskar Oil Engines Ltd, India \\
\hline Model & $\begin{array}{l}\text { TV-SR II, naturally aspirated } \\
\text { Engine } \\
\text { Single cylinder, direct injection } \\
\text { diesel engine }\end{array}$ \\
Bore/stroke/compression & Ratio $87.5 \mathrm{~mm} / 110 \mathrm{~mm} / 17.5: 1$ \\
Rated power & $5.2 \mathrm{Kw}$ \\
Speed & $1500 \mathrm{rpm}$, constant \\
Injection pressure/advance & $200 \mathrm{bar} / 23$ degree before TDC \\
Dynamometer & Eddy current \\
Type of starting manually & Air flow measurement Air box with \\
& U tube \\
Exhaust gas temperature & RTD thermocouple \\
Fuel flow measurement & Burette with digital stopwatch \\
Governor & Mechanical governing \\
Sensor response & Piezo electric \\
Time sampling & 4 micro seconds \\
Resolution crank & 1 degree crank angle \\
Angle sensor & 360 degree encoder with resolution \\
& of 1 degree \\
\hline
\end{tabular}

\subsection{Introduction}

\section{RESULTS AND DISCUSSION}

This chapter deals with experimental outcome of using waste plastic oil. FTIR and TGA analysis of waste plastic oil is presented. The output of the batch reactor is experimentally determined and waste plastic oil characterization is carried out and presented. Further different blends of plastic oil with diesel prepared. These blends are tested on single cylinder diesel engine to evaluate the combustion, emission and performance characteristics and compared with that of net diesel on single cylinder diesel engine and presented.

\subsection{Variation of yield of plastic oil at different temperature}

The sample collected for the pyrolysis oil is $1 \mathrm{~kg}$. The sample of plastic under test is subjected to the pyrolysis at $430^{\circ} \mathrm{C}, 460^{\circ} \mathrm{C}$ and $490^{\circ} \mathrm{C}$ respectively. The output of oil, char and vapor (by difference) for pyrolytic process are presented in the Table 4.1 . 
The variation of plastic oil output with respective to the different pyrolytic temperature are shown in Fig 4.1

Table 4.1.The output of oil, char and vapor for pyrolytic process

\begin{tabular}{|l|l|l|l|l|l|l|}
\hline $\begin{array}{l}\text { Temperatu } \\
\text { re }\end{array}$ & \multicolumn{2}{|l|}{ Oil extraction } & \multicolumn{2}{l|}{ Char } & \multicolumn{2}{l|}{ Vapor } \\
\hline$\left({ }^{\circ} \mathrm{C}\right)$ & $\begin{array}{l}\text { Gram } \\
\text { s }\end{array}$ & $\begin{array}{l}\text { Percenta } \\
\text { ge }(\%)\end{array}$ & $\begin{array}{l}\text { Gra } \\
\text { ms }\end{array}$ & $\begin{array}{l}\text { Percenta } \\
\text { ge }(\%)\end{array}$ & $\begin{array}{l}\text { Gra } \\
\text { ms }\end{array}$ & $\begin{array}{l}\text { Percenta } \\
\text { ge }(\%)\end{array}$ \\
\hline 430 & 244 & 24.4 & 350 & 35 & 354 & 35.4 \\
\hline 460 & 784 & 78.4 & 60 & 6 & 156 & 15.6 \\
\hline 490 & 732 & 73.2 & 20 & 2 & 248 & 24.8 \\
\hline
\end{tabular}

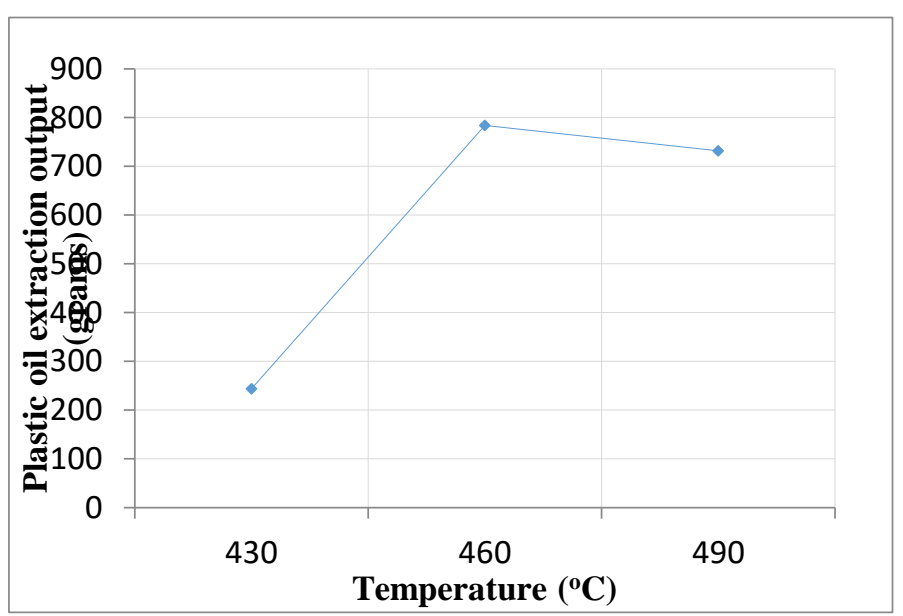

Fig 4.1 Variation of plastic oil output with respective to the different pyrolytic temperature

It is observed that these temperatures considerable amount of plastic oil has been collected. The maximum output of the plastic oil 784 grams $/ \mathrm{kg}$ is collected at $460^{\circ} \mathrm{C}$. It is further observed that the quantity collected reduces with increase in temperature and found minimum $0.2 \%$ at $490^{\circ} \mathrm{C}$.

\subsection{FTIR analysis of plastic oil}

The Fourier transform infrared spectroscopy (FTIR) of plastic oil is carried out in the ceramic and cement technology lab and their result are presented in the Fig 4.2. Plastic oil sample is subjected to the FTIR analysis to find out chemical combination of sample. The relative absorbance- wave number obtained from FTIR analysis is shown in Fig 4.2. It can be seen that there are 8 major peaks. Using characteristics infrared absorption band of functional group the class of compounds, their intensity and nature of bonds determined. Table 4.2 shows detail of compound and their characteristics pertaining to peaks observed in the FTIR analysis

Sample of the plastic oil consists of aromatic, alkenes, alkane and alkyls, carboxylic acids. Major peak assigns to the carboxylic acid, it has class of organic compound in which a carbon atom is bonded to an oxygen atom by a double bond and to a hydroxyl group $(-\mathrm{OH})$ by a single bond.

Alkane is a compound having single bonded open cycle saturated hydrocarbon molecules, for larger molecules exits. Example $\mathrm{CH}_{4}$ (methane), $\mathrm{C}_{2} \mathrm{H}_{6}$ (ethane), $\mathrm{C}_{3} \mathrm{H}_{8}$ (n-octane), $\mathrm{C}_{8} \mathrm{H}_{18}$ (iso-octane).

Alkenes compounds are open chain hydrocarbon containing a double bond and they unsaturated example $\mathrm{C}_{2} \mathrm{H}_{4}$ (ethane), $\mathrm{C}_{3} \mathrm{H}_{6}$ (propylene), $\mathrm{C}_{4} \mathrm{H}_{8}$ (butane) etc.

Benzene and its derivates where called aromatic compounds, which are having a cyclic structure with alternatively single band double bonds.

Plastic oil is similar to the diesel in structure. However additional hydroxyl group $(-\mathrm{OH})$ is bonded it means oxygen molecules are in built and available readily during combustion.

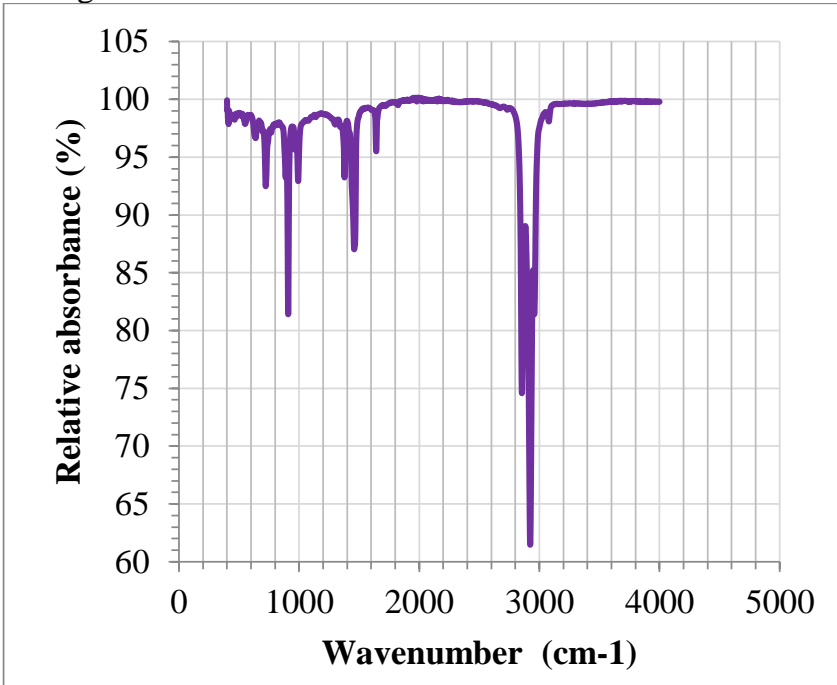

Fig 4.2 FTIR analysis of plastic oil sample

Table 4.2 Details of compounds and their characteristics parting to peaks observed in FTIR analysis

\begin{tabular}{|l|l|l|l|l|}
\hline Wave number $\mathrm{cm}^{-1}$ & Class of compounds & Intensity & Assignment & Relative absorbance \\
\hline 720 & Aromatic compound & Strong & C-H bend & $92 \%$ \\
\hline 910 & Alkenes & Medium+ Strong & $=\mathrm{C}-\mathrm{H}$ bend & $81 \%$ \\
\hline 990 & Alkenes & Medium+ Strong & $=\mathrm{C}-\mathrm{H}$ bend & $93 \%$ \\
\hline 1370 & Alkanes and alkyls & Medium & $\mathrm{CH}_{3} \mathrm{C}-\mathrm{H}$ bend & $93.5 \%$ \\
\hline 1460 & Alkanes and alkyls & Strong & $\mathrm{C}-\mathrm{H}$ bend & $87 \%$ \\
\hline 1640 & Alkenes & Very weak-medium & C=C stretch & $95.8 \%$ \\
\hline 2850 & Carboxylic acids & Strong, board & O-H stretch & $74.2 \%$ \\
\hline 2920 & Carboxylic acids & Strong, board & O-H stretch & $62.8 \%$ \\
\hline
\end{tabular}

4.4 Properties of plastic oil and diesel 
The density, kinematic viscosity, calorific value, flash and fire point of plastic oil and diesel used under test were carried out in the laboratory as per these IS standard. These values are presented in the Table 4.3. It is observed that density and calorific value of plastic oil is lower and kinematic viscosity is higher than that of diesel. The density, calorific value and viscosity of plastic oil are $82.9 \%, 80.88 \%$ and $184.65 \%$ of that of the pure diesel. The viscosity of plastic oil though it is $184.65 \%$ of that of diesel, it has sufficient value to obtain better spare and penetration. Flash and fire point of plastic oil are well comparable with that of diesel.

Table 4.3 Physical properties of Diesel and Plastic oil

\begin{tabular}{lll}
\hline $\begin{array}{l}\text { Physical } \\
\text { properties }\end{array}$ & Diesel & $\begin{array}{l}\text { Plastic } \\
\text { oil }\end{array}$ \\
\hline $\begin{array}{l}\text { Density } \\
\left(\mathbf{k g} / \mathbf{m}^{\mathbf{3}}\right)\end{array}$ & 890 & 738.16 \\
$\begin{array}{l}\text { Viscosity } \\
(\mathbf{c S t})\end{array}$ & 2.15 & 3.97 \\
$\begin{array}{l}\text { Calorific } \\
\text { value } \\
(\mathbf{k j} / \mathbf{k g})\end{array}$ & 42500 & 34374.73 \\
$\begin{array}{l}\text { Flash } \\
\text { point }\end{array}$ & 45 & 42 \\
Fire point & 50 & 47
\end{tabular}

\subsection{Combustion characteristics Variation of cylinder pressure with crank angle}

Fig 4.3 shows the variation of cylinder pressure with respective crank angle at maximum load. It can be observed that the trend of pressure variation for the fuel under the test is similar. Pressure of D70P30 is higher followed by D80P20, D90P10 and D100 respectively. Fig 4.4 shows difference of peak cylinder pressure at maximum load for all the fuel under the test. From $20 \%$ to $100 \%$ of load the cylinder pressure of the D70P30 is higher compared to other fuels. However difference of pressure between D90P10, D80P20 is almost same and little higher than that of D100. At highest load peak cylinder pressure D70P30 is 63.47 bars against $62.08,61.33$ and 60.27 bars for D80P20, D90P10 and D100 respectively.

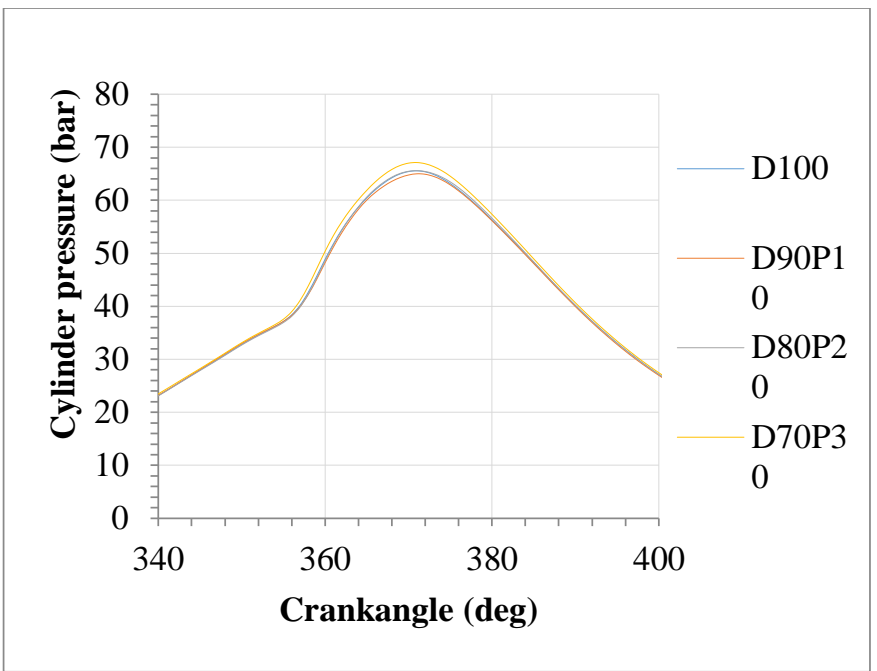

Fig 4.3 Variation of cylinder pressure with crank angle

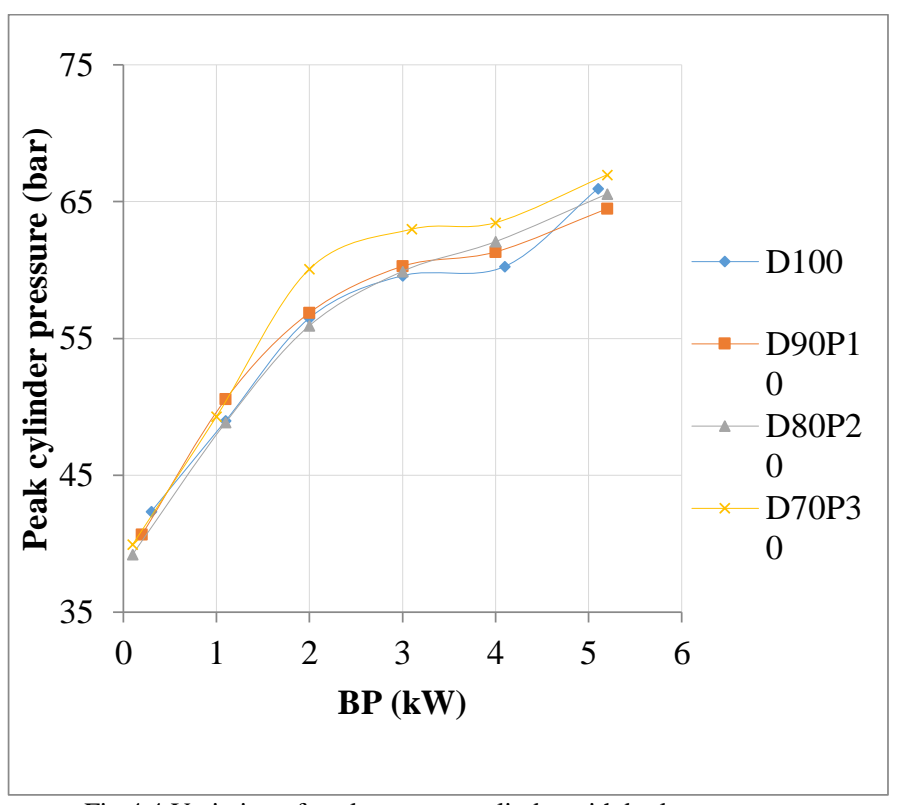

Fig 4.4 Variation of peak pressure cylinder with brake power

\section{Variation of net heat release rate with crank angle}

Fig 4.5 shows variation of net heat release rate with crank angle at full load. Rate of heat release for D70P30 is higher compared to other fuels under the test. Clearly it indicates that increase in percentage of plastic oil in diesel improved the combustion quality and higher pressure in cylinder Fig 4.3. 


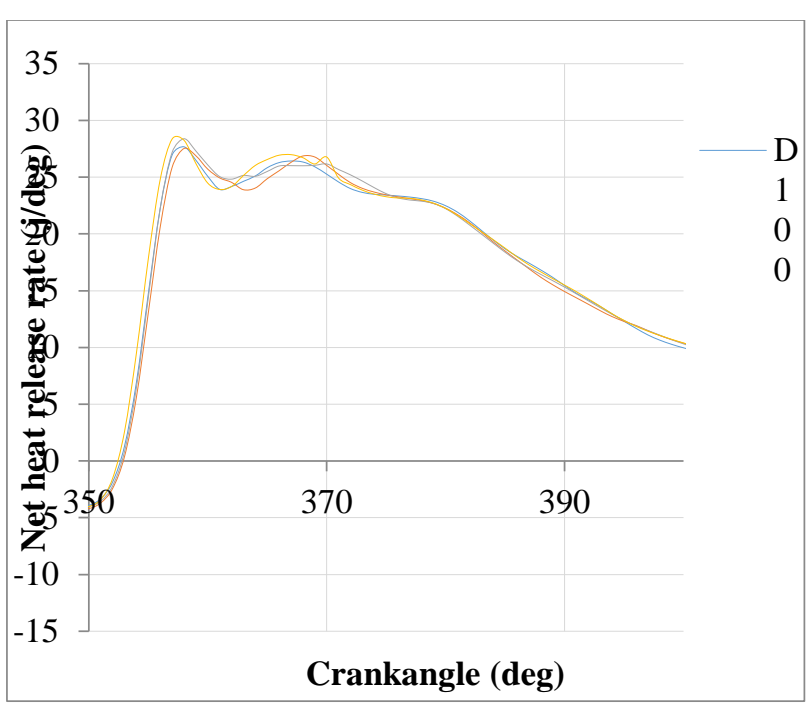

Fig 4.5 Variation of net heat release rate with crank angle

\subsection{Emission characteristics}

Variation of smoke with respective to the brake power

Fig 4.6 shows variation of smoke with brake power. Smoke emission increases as the load increases for all the fuels under test. It is observed that smoke of diesel D90P10, D100 is almost same. However by increase in percentage of plastic oilin blend proportionality smoke emission increases, at maximum load smoke emission of D70P30 is $92.9 \%$ opacity against $98.3 \%, 97 \%, 98.4 \%$ opacity that of D100, D90P10, D80P20 respectively. As the load increases the quantity of fuel injected in the cylinder increases because of this mixture becomes rich mixture and smoke emission increases.

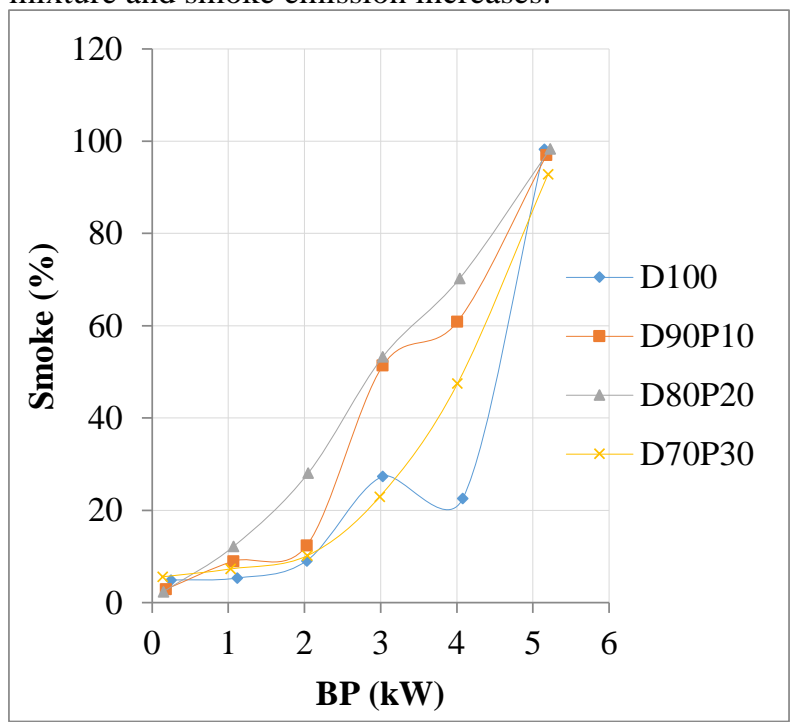

Fig 4.6 Variation of smoke with brake power

\section{Variation of carbon monoxide with brake power}

Fig 4.7 shows variation of carbon monoxide in percentage with brake power in kilowatt. Up to $80 \%$ of load $\mathrm{CO}$ emission of all the fuel under test decreases and at full load increase. At full load smoke emission D70P30 is 0.77 against $0.76,0.51$ and 0.51 of D80P20, D90P10 and D100 respectively. At maximum load as the mixture becomes rich, due to this some of the carbons are not converted into carbon dioxide.

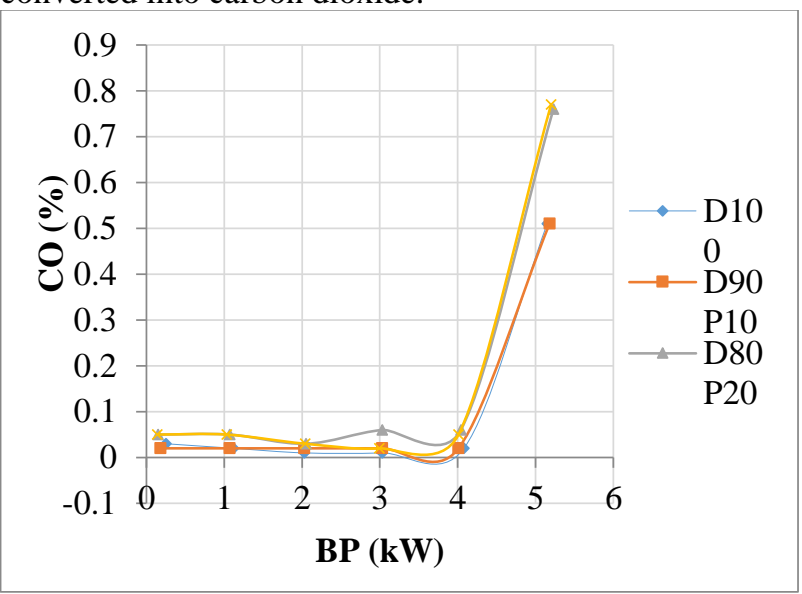

Fig 4.7 Variation of carbon monoxide with brake power

\section{Variation of unburnt hydrocarbon with brake power}

Fig 4.8 shows variation of unburnt hydrocarbon with brake power. It is observed that unburnt hydrocarbon increases as the load increases for all the fuel under test. As the percentage of plastic oil in the blend increases the unburnt hydrocarbon also increases. At maximum load the unburnt hydrocarbon is 106, 95, 115 and 118 part per million (ppm) for D100, D90P10, D80P20 and D70P30. As already mentioned that as the load increases the quantity of fuel injected increases which makes fuel rich mixture, due to quenching and crives flows the unburnt hydrocarbon exhaust increases.

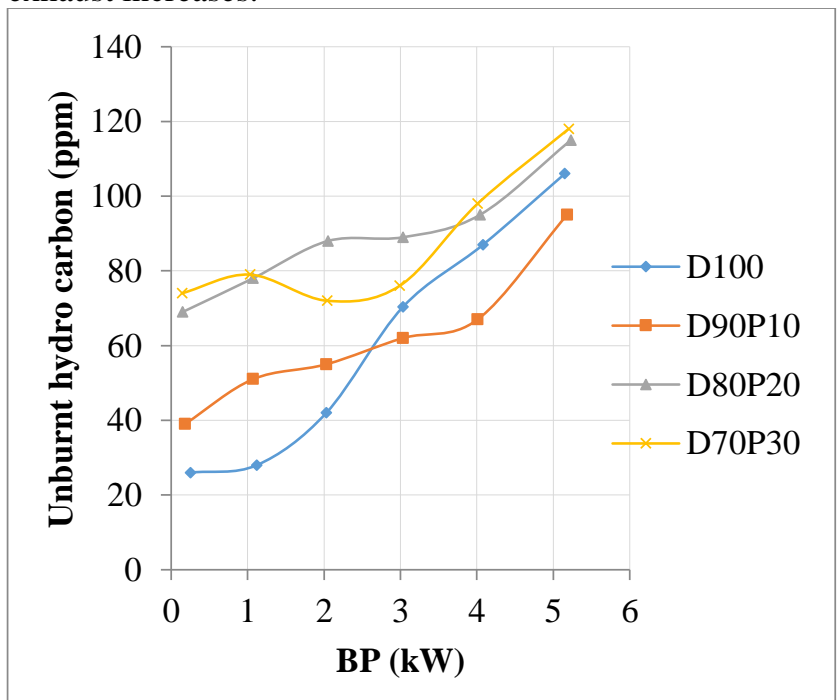

Fig 4.8 Variation of unburnt hydrocarbon with brake power

\section{Variation of oxides of nitrogen with respective to the brake power}

Fig 4.9 shows the variation of oxides of nitrogen with brake power. $\mathrm{NO}_{\mathrm{X}}$ emission increases with increases in the load. Higher the percentage of plastic oil in the blend leads to the higher $\mathrm{NO}_{\mathrm{X}}$ emission. Complete combustion of the plastic oil blends leads to higher exhaust gas temperature Fig 4.10.Plastic oil consists of oxygen molecules in its structure in addition to carbon and 
hydrogen. The oxygen readily available for combustion where a part of this oxygen reacts with nitrogen forms $\mathrm{NO}_{\mathrm{X}}$ emission increases. Further as the load increases more amount of oil is injected and mixture becomes rich, so it emits higher $\mathrm{NO}_{\mathrm{X}}$.

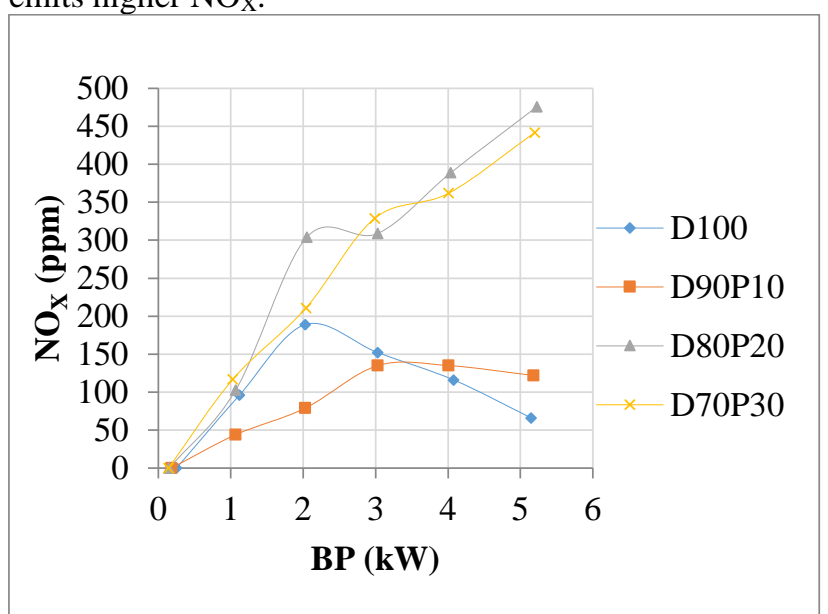

Fig 4.9 Variation of oxides of nitrogen with brake power

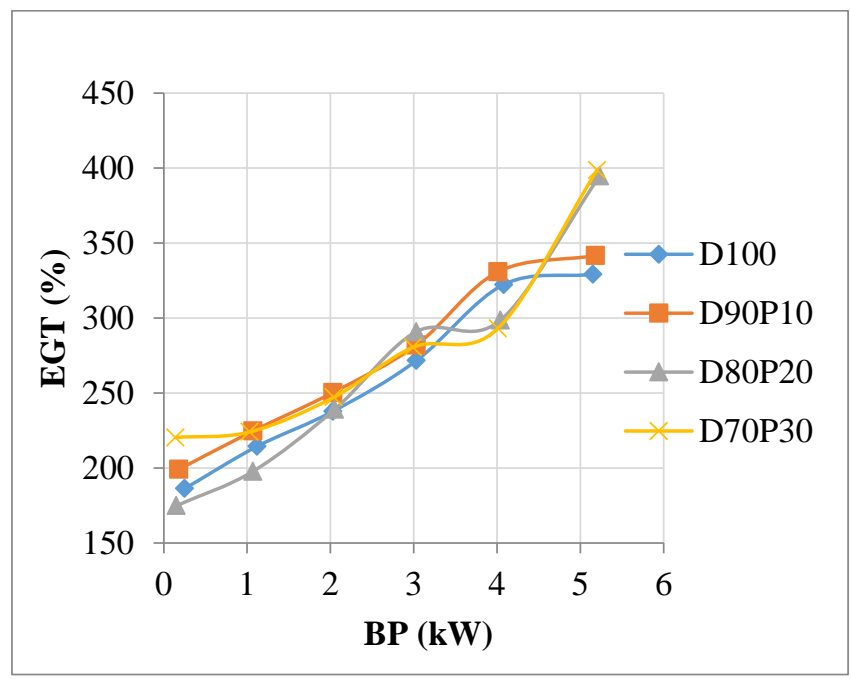

Fig 4.10 Variation of exhaust gas temperature with brake power

\subsection{Performance characteristics \\ Variation of brake thermal efficiency with brake power}

Fig 4.11 shows the variation of brake thermal efficiency with brake power. The maximum brake thermal efficiency occurs at $80 \%$ of the load. As the load increases the quantity of fuel injected into the cylinder also increases, which leads to higher power development. The blends having D70P30 is having higher brake thermal efficiency at all load, followed by D80P20, D90P10 and D100. The maximum efficiency of D70P30 is $28.03 \%$ against $27.03 \%$, $27.07 \%$ and $25.68 \%$ of D80P20, D90P10 and D100 respectively.

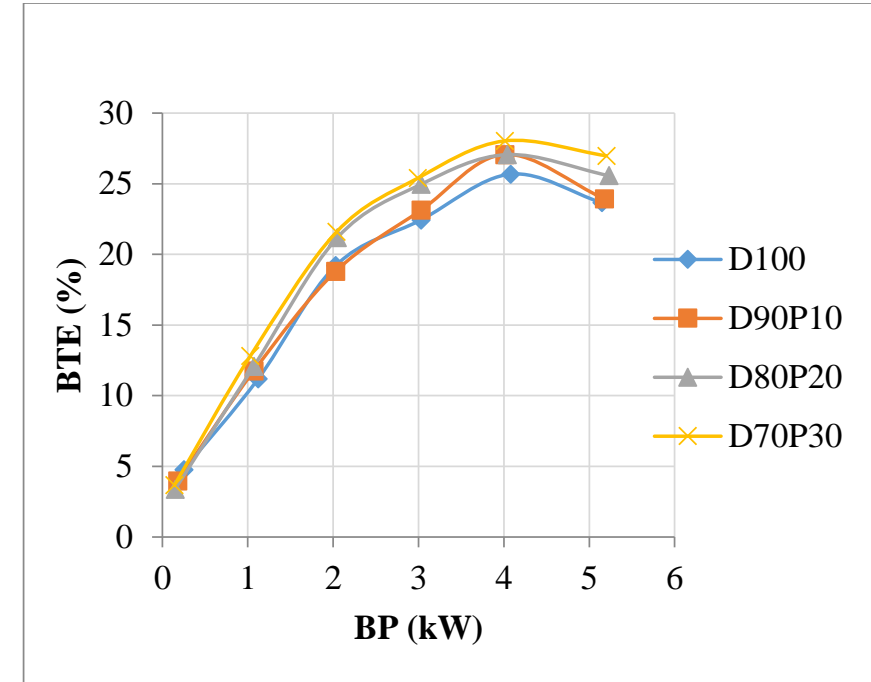

Fig 4.11 Variation of brake thermal efficiency with brake power

\section{Variation of brake specific fuel consumption and brake} specific energy consumption with brake power

Fig 4.12 shows variation of brake specific fuel consumption (BSFC) with brake power and Fig 4.13 shows the variation of brake specific energy consumption (BSEC) with brake power respectively. BSFC curve is reverse of brake thermal efficiency. The minimum BSFC of D70P30, D80P20, D90P10 and D100 are 0.33, 0.27, 0.32 and 0.33 $\mathrm{kg} / \mathrm{kWh}$. However BSEC is better tool to measure the performance of the engine. It is found that minimum BSEC of D70P30, D80P20, D90P10 and D100 are respectively $10416,11036,14456$ and $13600 \mathrm{~kg} / \mathrm{kWh}$ respectively.

Better combustion, higher heat release and increase in the cylinder pressure leads to better performance among all the oils tested D70P30 are better compared to other fuels.

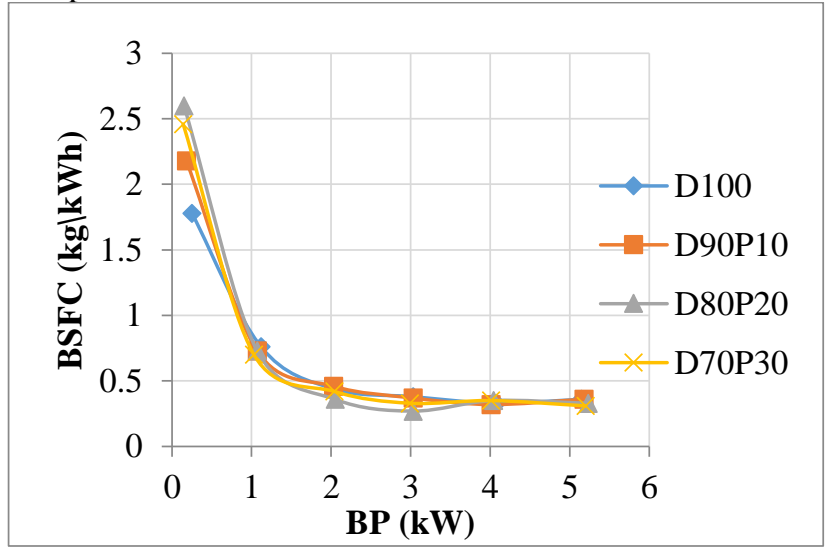

Fig 4.12 Variation of brake specific fuel consumption with brake power 


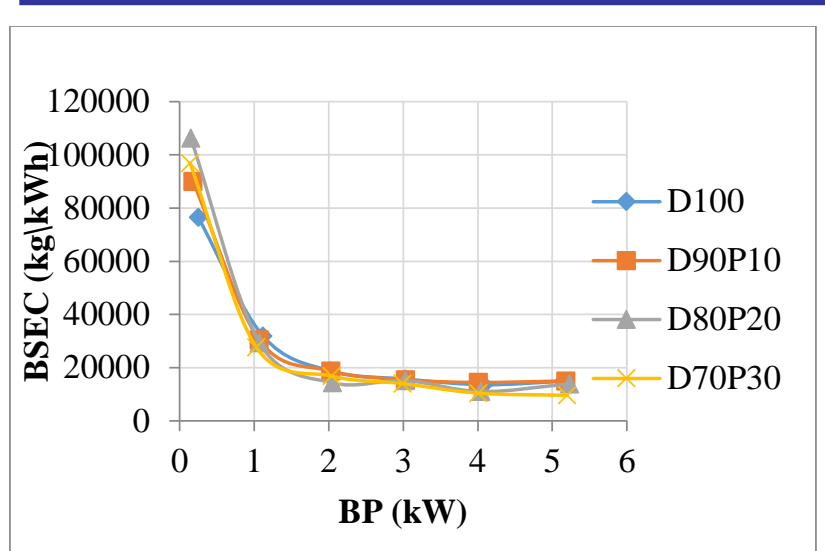

Fig 4.13 Variation of brake specific energy consumption with brake power

\section{CONCLUSIONS}

Following are the conclusion drawn from the experiment/project.

- Higher plastic oil yield occurs at $460^{\circ} \mathrm{C}$, which equal to $784 \mathrm{grams} / \mathrm{kg}$.

- Plastic oil consists of additional oxygen molecules (hydroxyl group) in its structure.

- Density, calorific value for plastic oil is lower and viscosity is higher than that of diesel.

- Flash and fire point of plastic oil are well comparable with diesel.

- Brake thermal efficiency is higher than of pure diesel.

- As the $\%$ of plastic oil increases in the blend, the performance of the engine is better.

- Smoke, unburnt hydrocarbon and $\mathrm{NO}_{\mathrm{x}}$ emission increases with \% of plastic oil in the blends.

\section{REFERANCES}

[1] Plastic waste management issues, solution and case studies; ministry of housing \& urban affairs govt of India, 2019.

[2] Plastic foundation; report on India plastic industry ISO 9001-2008 certified; plastic India empowering growth-2018 ;January-2018। Edition-2.

[3] World environment day fact sheet on plastic waste India -2018, Teri; The energy and resource institute.

[4] Future scenario of globally plastic waste generation and disposal; Laurent lebreton \& Anthony Andrady 29 Jan-2019

[5] Cepeliogullar O, Putun AE. Utilization of two different types of plastic wastes from daily and industrial life. In: Ozdemir C, Sahinkaya S, Kalipci E, Oden MK, editors. ICOEST Cappadocia 2013. Turkey: ICOEST Cappadocia; 2013. p. 1-13.

[6] Fakhrhoseini SM, Dastanian M. Predicting pyrolysis products of PE, PP, and PET using NRTL activity coefficient model. Hindawi Publishing Corporation; 2013. p. 1-5.

[7] Ahmad I, Khan MI, Khan H, Ishaq M, Tariq R, Gul K, et al. Pyrolysis study of polypropylene and polyethylene into premium oil products. Int J Green Energy 2014; 12:663-71.

[8] Kumar S, Singh RK. Recovery of hydrocarbon liquid from waste high density polyethylene by thermal pyrolysis. Braz J Chem Eng 2011;28:659-67.

[9] Marcilla A, Beltrán MI, Navarro R. Thermal and catalytic pyrolysis of polyethylene over HZSM5 and HUSY zeolites in a batch reactor under dynamic conditions. Appl Catal B Environ 2009;86:78-86.

[10] Mastral FJ, Esperanza E, Garcia P, Juste M. Pyrolysis of highdensity polyethylene in a fluidized bed reactor. Influence of the temperature and residence time. J Anal Appl Pyrol 2001;63:1-15.

[11] Bagri R, Williams PT. Catalytic pyrolysis of polyethylene. J Anal Appl Pyrol 2001;63:29-41.

[12] Uddin MA, Koizumi K, Murata K, Sakata Y. Thermal and catalytic degradation of structurally different types of polyethylene into fuel oil. Polym Degrad Stab 1996:56:37- 44. Aguado J, Serrano DP, San Miguel G, Castro MC, Madrid S. Feedstock recycling of polyethylene in a two-step thermo-catalytic reaction system. J Anal Appl Pyrol 2007;79:415-23.

[13] Aguado J, Serrano DP, San Miguel G, Castro MC, Madrid S. Feedstock recyclingof polyethylene in a two-step thermocatalytic reaction system. J Anal Appl Pyrol 2007;79:415-23.

[14] Onwudili JA, Insura N, Williams PT. Composition of products from the pyrolysis of polyethylene and polystyrene in a closed batch reactor: effects of temperature and residence time. J Anal Appl Pyrol 2009;86:293-303.

[15] Sakata Y, Uddin MA, Muto A. Degradation of polyethylene and polypropylene into fuel oil by using solid acid and non-solid acid catalysts. J Anal Appl Pyrol 1999;51:135-55.

[16] Demirbas A. Pyrolysis of municipal plastic wastes for recovery of gasolinerange hydrocarbons. J Anal Appl Pyrol 2004;72:97-102.

[17] Liu Y, Qian J, Wang J. Pyrolysis of polystyrene waste in a fluidizedbed reactor to obtain styrene monomer and gasoline fraction. Fuel Process Technol 1999;63:45-55.

[18] Miranda R, Jin Y, Roy C, Vasile C. Vacuum pyrolysis of PVC kinetic study. Polym Degrad Stab 1998;64:127-44.

[19] Chin BLF, Yusup S, Al Shoaibi A, Kannan P, Srinivasakannan C, Sulaiman SA. Kinetic studies of co-pyrolysis of rubber seed shell with high density polyethylene. Energy Convers Manage 2014;87:746-53.

[20] Murata K, Sato K, Sakata Y. Effect of pressure on thermal degradation of polyethylene. J Anal Appl Pyrol 2004;71:569-89.

[21] Cardona SC, Corma A. Tertiary recycling of polypropylene by catalytic cracking in semibatch stirred reactor: use of spent equilibrium FCC commercial catalyst. Appl Catal B Environ 2000;25:151-62.

[22] Abbas-Abadi MS, Haghighi MN, Yeganeh H, McDonald AG Evaluation of pyrolysis process parameters on polypropylene degradation products. J Anal Appl Pyrol 2014;109:272-7.

[23] Seo Y-H, Lee K-H, Shin D-H. Investigation of catalytic degradation of highdensity polyethylene by hydrocarbon group type analysis. J Anal Appl Pyrol 2003;70:383-98.

[24] Onu P, Vasile C, Ciocilteu S, Iojoiu E, Darie H. Thermal and catalytic decomposition of polyethylene and polypropylene. J Anal Appl Pyrol 1998;49:145-53.

[25] Jung S-H, Cho M-H, Kang B-S, Kim J-S. Pyrolysis of a fraction of waste polypropylene and polyethylene for the recovery of BTX aromatics using a fluidized bed reactor. Fuel Process Technol 2010;91:277-84.

[26] Luo G, Suto T, Yasu S, Kato K. Catalytic degradation of high density polyethylene and polypropylene into liquid fuel in a powder-particle fluidized bed. Polym Degrad Stab 2000;70:97-102.

[27] Olazar M, Lopez G, Amutio M, Elordi G, Aguado R, Bilbao J. Influence of FCC catalyst

[28] steaming on HDPE pyrolysis product distribution. J Anal Appl Pyrol 2009;85:359-65.

[29] Elordi G, Olazar M, Aguado R, Lopez G, Arabiourrutia M, Bilbao J. Catalytic pyrolysis of high density polyethylene in a conical spouted bed reactor. J Anal Appl Pyrol 2007;79:450-5.

[30] Arabiourrutia M, Elordi G, Lopez G, Borsella E, Bilbao J, Olazar M. Characterization of the waxes obtained by the pyrolysis of polyolefin plastics in a conical spouted bed reactor. J Anal Appl Pyrol 2012;94:230-7.

[31] Williams PT, Williams EA. Fluidised bed pyrolysis of low density polyethylene to produce petrochemical feedstock. J Anal Appl Pyrol 1998;51:107-26. 